\title{
Steroid $5 \alpha$-reductase isozymes in the adult female rat brain: central role of dihydrotestosterone
}

\author{
JM Torres ${ }^{1,2}$ and E Ortega ${ }^{1,2}$ \\ 'Department of Biochemistry and Molecular Biology, Faculty of Medicine, University of Granada, Avda. de Madrid s/n, 18012 Granada, Spain \\ ${ }^{2}$ Institute of Neurosciences, University of Granada, 18012 Granada, Spain \\ (Requests for offprints should be addressed to E Ortega; Department of Biochemistry and Molecular Biology, University of Granada, Email: esortega@ugr.es)
}

\begin{abstract}

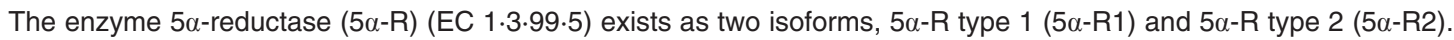
$5 \alpha-\mathrm{R} 1$ has been associated with catabolic functions whereas $5 \alpha-\mathrm{R} 2$ has been associated with sexually dimorphic functions of the male. We recently demonstrated that both $5 \alpha-\mathrm{R}$ isozymes are present in the central nervous system (CNS) of the adult male rat and are regulated in an opposing way by androgens. This finding raises the question as to whether both isozymes play a role in the sexual dimorphism of the CNS, besides other functions. To test this hypothesis, it is essential to study the regulation of both isozymes by androgens in the female. In this work, we studied the effects of testosterone (T) and dihydrotestosterone (DHT) on mRNA levels of both $5 \alpha-\mathrm{R}$ isoforms in the prefrontal cortex of the adult female rat by one-step quantitative RT-PCR coupled with laser-induced fluorescence capillary electrophoresis. Our results demonstrate for the first time that $5 \alpha-R 2$ mRNA is slightly regulated by T and DHT in females. Surprisingly, $5 \alpha-R 1$ mRNA is not regulated by $T$ in the intact female, whereas it is very positively regulated by $\mathrm{DHT}$, a more potent androgen than T. These data indicate the great sexual dimorphism in the CNS with respect to both $5 \alpha-R$ isozymes, and suggest a crucial role of DHT in the sexual dimorphism of the CNS in the female. These results open up a new research line that may lead to a better understanding of the physiology of the CNS.
\end{abstract}

Journal of Molecular Endocrinology (2006) 36, 239-245

\section{Introduction}

The physiological importance of $5 \alpha$-reductase $(5 \alpha-\mathrm{R})$ (EC $1 \cdot 3 \cdot 99 \cdot 5)$ in the brain may derive from two of its properties: its capability to convert testosterone (T) to a more potent androgen, dihydrotestosterone (DHT), that appears to participate in the sexual differentiation processes of some brain regions (Lauber \& Lichtensteiger 1996, Poletti et al. 1997,1998b, Melcangi et al. 1998, Torres \& Ortega 2003a); and its capability to convert progesterone and deoxycorticosterone (DOC) to their respective $5 \alpha$-reduced derivatives, precursors of allopregnanolone and tetrahydroDOC, potent allosteric modulators of the $\gamma$-aminobutyric acid receptor $\left(\mathrm{GABA}_{\mathrm{A}}-\mathrm{R}\right)$ (Mellon \& Griffin 2002), which participates in the regulation of various psychophysiological phenomena (Purdy et al. 1991, Majewska 1992, Melcangi et al. 2005, Patte-Mensah et al. 2005). The enzyme $5 \alpha$-Reductase $(5 \alpha-\mathrm{R})(\mathrm{EC} 1 \cdot 3 \cdot 99 \cdot 5)$ exists as two isoforms, $5 \alpha-\mathrm{R}$ type $1(5 \alpha-\mathrm{R} 1)$ and $5 \alpha-\mathrm{R}$ type $2(5 \alpha-\mathrm{R} 2)$ and both are present in the brain. The predominant mRNA species in rat brain is $5 \alpha-\mathrm{R} 1$ (Lephart 1993), which has been proposed as a constitutive enzyme that essentially plays a catabolic and neuron protective role (Poletti et al. 1998b). 5a-R2 participates in sexually dimorphic functions of the male, such as in the development of prostate and external genitalia and in the differentiation of the CNS (Russell \& Wilson 1994, Poletti et al. 1998b).

In order to determine the brain regions as well as the nerve cell types which contain $5 \alpha-\mathrm{R}$, Pelletier et al. (1994) studied the immunocytochemical localization of the enzyme, finding the immunoreactive material located in several brain areas including hypothalamus, amigdala, hippocampus, cerebellum and cerebral cortex. Moreover, Melcangi et al. (1993) reported $5 \alpha-\mathrm{R}$ activity in primary cell cultures of neurons, oligodendrocytes, and astrocytes obtained from rat brain.

We recently demonstrated that these $5 \alpha-\mathrm{R}$ isozymes are regulated in the male CNS in an opposing manner by androgens (Torres \& Ortega 2003a), suggesting that both isozymes may play a role in the sexual dimorphism of the CNS, besides other functions (Paul \& Purdy 1992, Torres \& Ortega 2003b). We proposed that 5 $\alpha$-R2 participates in masculinization processes in male rats, whereas $5 \alpha-\mathrm{R} 1$ may be involved in the feminization of the brain. In order to test this hypothesis, it is of maximal interest to know the mRNA levels of both $5 \alpha-R$ isozymes in the brain of female rats and their regulation by androgens, determining sexually dimorphic differences in these isozymes. To our knowledge, this issue has not been addressed in the literature. 
Table 1 Primer sequences and PCR products

\begin{tabular}{llll} 
& Primer sequence $\left(5^{\prime}-3^{\prime}\right)$ & \multirow{2}{*}{ Size (bp) } \\
\cline { 2 - 3 } Name & \multicolumn{2}{c}{185} \\
R1-F & GAGATATTCAGCTGAGACCC & \\
R1-R & TTAGTATGTGGGCAGCTTGG & \\
R2-F & ATTTGTGTGGCAGAGAGAGG & \\
R2-R & TTGATTGACTGCCTGGATGG & \multirow{2}{*}{300} \\
IS1-F & GAGATATTCAGCTGAGACCCACGTAAACGCCCACAAGTTC & \\
IS1-R & TTAGTATGTGGGCAGCTTGGTCTTGTAGTTGCCGTCGTCC & \\
IS2-F & ATTTGTGTGGCAGAGAGAGGACGTAAACGGCCACAAGTTC & 300 \\
IS2-R & TTGATTGACTGCCTGGATGGTCTTGTAGTTGCCGTCGTCC &
\end{tabular}

Analysis of mRNA levels of specific genes may allow an estimation of gene expression. The present paper aimed to study $5 \alpha-\mathrm{R}$ isozymes mRNA levels and their regulation by $\mathrm{T}$ and DHT in the prefrontal cortex of adult female rats, using a method that combines the high specificity of one-step quantitative RT-PCR with the sensitivity of laser-induced fluorescence capillary electrophoresis (LIF-CE). In this study we have used the same experimental procedure that was previously reported in males (Torres \& Ortega 2003a) to enable a direct comparison of the results between males and females.

\section{Materials and methods}

\section{Animals}

Adult female Wistar rats weighing 180-200 g were housed in an air-conditioned room with fluorescent lights on from $7 \cdot 00$ to $1900 \mathrm{~h}$, and were given standard laboratory pellet chow and water ad libitum. Experiments were made in strict accordance with the NIH guide for the Care and Use of Laboratory Animals. The experimental groups studied were: intact rats $(\mathbf{I})$, intact rats plus $\mathrm{T}(\mathrm{I}+\mathrm{T})$, intact rats plus DHT $(\mathrm{I}+\mathrm{DHT})$, ovariectomized rats $(\mathrm{OVX})$, ovariectomized rats plus $\mathrm{T}$ $(\mathrm{OVX}+\mathrm{T})$ and ovariectomized rats plus DHT $(\mathrm{OVX}+\mathrm{DHT})$. Groups I+T and OVX+T were injected s.c. with oil vehicle $(20 \%$ ethanol in sesame oil $)$ containing $\mathrm{T}$ propionate $\left(\mathrm{T}_{\mathrm{p}} ; 1 \mathrm{mg} / \mathrm{kg}\right.$ body weight/day) (George et al. 1991) on days 0, 3, 6, 9 and 12, a final injection was given $3 \mathrm{~h}$ before decapitation on day 15 . To enable comparison of the effects of $\mathrm{T}$ and DHT, groups I+DHT and OVX+DHT were injected s.c. with oil vehicle $(20 \%$ ethanol in sesame oil) containing DHT propionate $\left(\mathrm{D}_{\mathrm{p}} ; 1 \mathrm{mg} / \mathrm{kg}\right.$ body weight/ day) (George et al. 1991) on the same days (days 0, 3, 6, 9, 12 and 15). I and OVX groups were injected s.c. on the same days with oil vehicle alone. The number of rats per group was 10. The animals were decapitated, and the brain was removed and weighed. Prefrontal cortex samples were frozen in liquid nitrogen and stored at $-80^{\circ} \mathrm{C}$ until analysis. Blood samples were collected in heparinized tubes. After coagulation, the blood was centrifuged at $800 \boldsymbol{g}$ for $10 \mathrm{~min}$. The plasma was separated and stored at $-20{ }^{\circ} \mathrm{C}$ until the hormonal measurements were performed.

\section{Hormone assays}

Plasma T concentrations were measured by RIA using a commercial DiaSorin (Vercelli, Italy) kit without modification. The intra- and inter-assay coefficients of variation were $7 \cdot 6 \%$ and $12.0 \%$, respectively, the sensitivity was $0.05 \mathrm{ng} / \mathrm{ml}$, and the cross-reactivity of the antiserum was $6.9 \%$ for DHT. Plasma DHT concentrations were measured by direct ELISA (Diagnostic Biochem Canada Inc., Ontario, Canada). The intra-and inter-assay coefficients of variation were $5.9 \%$ and $7.5 \%$, respectively, the sensitivity was $6.0 \mathrm{pg} / \mathrm{ml}$, and the cross-reactivity of the antiserum was $8 \cdot 7 \%$ for $\mathrm{T}$.

\section{Oligonucleotides used for amplifications}

Sequences of rat $5 \alpha-\mathrm{R}$ isozymes were obtained from GeneBank and the sequence of plasmid pEGFP-C1 was obtained from the Clontech web page (www.clontech. com). These sequences were used to design the primer pairs. Primers for $5 \alpha-\mathrm{R}$ isozymes were $20 \mathrm{bp}$ of length, whereas primers used to synthesize both competitor molecules were $40 \mathrm{bp}$ of length. All forward primers were end-labeled with 6-carboxy-fluorescein. Oligonucleotides were synthesized by PE-Applied Biosystems, UK. Primer sequences $\left(5^{\prime}-3^{\prime}\right)$ and PCR product sizes are presented in Table 1.

\section{Construction of the internal standard template}

Two synthetic internal standard (IS) DNAs of 300-bp were synthesized from the sequence of plasmid pEGFP-C1 (Clontech, Palo Alto, CA, USA) following Torres and Ortega (2004a). Both competitive molecules, IS- 1 (competitor DNA of $5 \alpha-\mathrm{R} 1$ ) and IS-2 (competitor DNA of $5 \alpha-R 2)$ were obtained after two consecutive amplifications from pEGFP-C1, with $5^{\prime}$ and $3^{\prime}$ ends 
modified to contain the same nucleotide sequences as SRD5A1 or SRD5A2 (Torres \& Ortega 2004a).

\section{RT-PCR}

Total RNA was extracted from $25 \mathrm{mg}$ of rat prefrontal cortex tissues by acid-guanidinium thiocyanate-phenolchloroform (Chomczynski \& Sacchi 1987). The RNA was resuspended in diethyl pyrocarbonate-treated water and quantitated spectrophotometrically for analysis. First-strand cDNA was carried out according to Torres et al. (2004). The PCR profile was: denaturing, $94{ }^{\circ} \mathrm{C}$ for $30 \mathrm{~s}$; annealing, $55^{\circ} \mathrm{C}$ for $30 \mathrm{~s}$; and extension, $72^{\circ} \mathrm{C}$ for $30 \mathrm{~s}$. In each case the number of cycles was 35 . PCR was carried out in a Perkin-Elmer 2400 Thermal Cycler.

\section{Analysis of PCR products}

A CE system with LIF detection was used to characterize RT-PCR products. After amplification, an aliquot of the sample $(1 \mu \mathrm{l})$ was diluted $1 / 20$ with $18.5 \mu \mathrm{l}$ of formamide and $0.5 \mu \mathrm{l}$ of GeneScan-500 TAMRA Size Standard (Applied Biosystem, Warrington, UK) and denatured at $95{ }^{\circ} \mathrm{C}$ for $3 \mathrm{~min}$. Capillary electrophoresis was carried out in a $47 \mathrm{~cm}$-silica capillary containing POP-4 polymer (Applied Biosystem, Branchburgh, NJ, USA). The separation capillary was first filled with the polymer solution. The sample was then injected into the separation capillary for $5 \mathrm{~s}$. The temperature of the separation capillary was $60{ }^{\circ} \mathrm{C}$ and each sample ran for $24 \mathrm{~min}$ at $100 \mathrm{~V} / \mathrm{cm}$. We performed LIF-CE in an ABIPRISM 310 Genetic Analyzer (Applied Biosystem).

The ratios of fluorescence of both $5 \alpha$-R/IS were plotted against the amount of the appropriate competitive DNA, and the concentration of target DNA in the sample was calculated according to Torres \& Ortega $(2004 a)$. The concentration of problem cDNA was corrected by the correction factor $\mathrm{K}$. The correction factor K depends on the RT-PCR characteristics and is the product of three components that represent the correction due to the difference in size between problem and standard; the correction due to the addition of the internal standard in DNA form, and the efficiency of retrotranscription (Torres \& Ortega $2004 a$ ).

\section{Statistical analysis}

Statistically significant differences between the groups were analyzed by a two-way ANOVA. The Bonferroni method was used in this study. The SPSS version $9 \cdot 0$ for Windows software package was used in the statistical analysis. Results are expressed as mean \pm S.E.M.

\section{Results}

\section{Serum hormonal levels}

We found that the $\mathrm{T}$ levels in OVX animals $(0.2 \pm 0.09 \mathrm{ng} / \mathrm{ml})$ were lower than those in I animals $(0.3 \pm 0.08 \mathrm{ng} / \mathrm{ml})$. After T treatment, there was a significant increase in T levels in both I $(10.26 \pm 0.5 \mathrm{ng} / \mathrm{ml}$, $P<0.001)$ and OVX $(9.5 \pm 0.5 \mathrm{ng} / \mathrm{ml}, P<0.001)$ rats in comparison with their pre-treatment levels.

We found that the DHT levels in OVX animals $(49 \pm 11 \mathrm{pg} / \mathrm{ml})$ were lower than those in I animals $(78 \pm 21 \mathrm{pg} / \mathrm{ml})$. After DHT treatment, there was a significant increase in DHT levels in both I $(750 \pm 60 \mathrm{pg} / \mathrm{ml}, P<0 \cdot 001)$ and OVX $(500 \pm 40 \mathrm{pg} / \mathrm{ml}$, $P<0.001)$ animals in comparison with their respective pre-treatment levels.

\section{Quantification of $5 \alpha-R 1$ mRNA levels in prefrontal cortex}

The amount of mRNA was expressed as number of mRNA copies per $100 \mathrm{ng}$ of total RNA. After cDNA was generated from total RNA by RT reaction, it was co-amplified in the presence of decreasing amounts of the competitive DNA $\left(64 \times 10^{6}-0.5 \times 10^{6}\right.$ molecules $)$. We co-amplified $5 \alpha-\mathrm{R} 1 \mathrm{cDNA}$ and the competitive standard DNA IS- 1 using the same pair of primers. With decreasing amounts of the competitive DNA, the relative intensity of amplified product of target DNA increased.

The mean amount of $5 \alpha-\mathrm{R} 1 \mathrm{mRNA}$ in the prefrontal cortex of the different experimental groups is displayed in Fig. 1. The 5 $\alpha$-R1 mRNA levels in OVX animals were 1.4-fold than in I animals. After T treatment, there was not a significant increase of $1 \cdot 04$-fold in I rats in comparison with its respective pre-treatment levels. After DHT treatment, there was a significant increase of 4.5-fold in I rats in comparison with its respective pre-treatment levels. After T and DHT treatment, there was a significant increase in 5 $\alpha-\mathrm{R} 1 \mathrm{mRNA}$ levels in OVX animals in comparison with their respective pre-treatment levels $(1 \cdot 7$-fold for $\mathrm{T}$ and $2 \cdot 9$-fold for DHT, respectively).

\section{Quantification of $5 \alpha-R 2$ mRNA levels in prefrontal cortex}

In the same way, we co-amplified $5 \alpha-\mathrm{R} 2 \mathrm{cDNA}$ and the competitive standard DNA IS-2 using the same pair of primers. With decreasing amounts of the competitive DNA, the relative intensity of amplified product of target DNA increased. Thus, the ratio of fluorescence of $5 \alpha-\mathrm{R} 2 /$ IS-2 was plotted against the amount of competitive DNA IS-2.

The mean amount of $5 \alpha-\mathrm{R} 2$ mRNA in the prefrontal cortex of the different experimental groups is shown in 


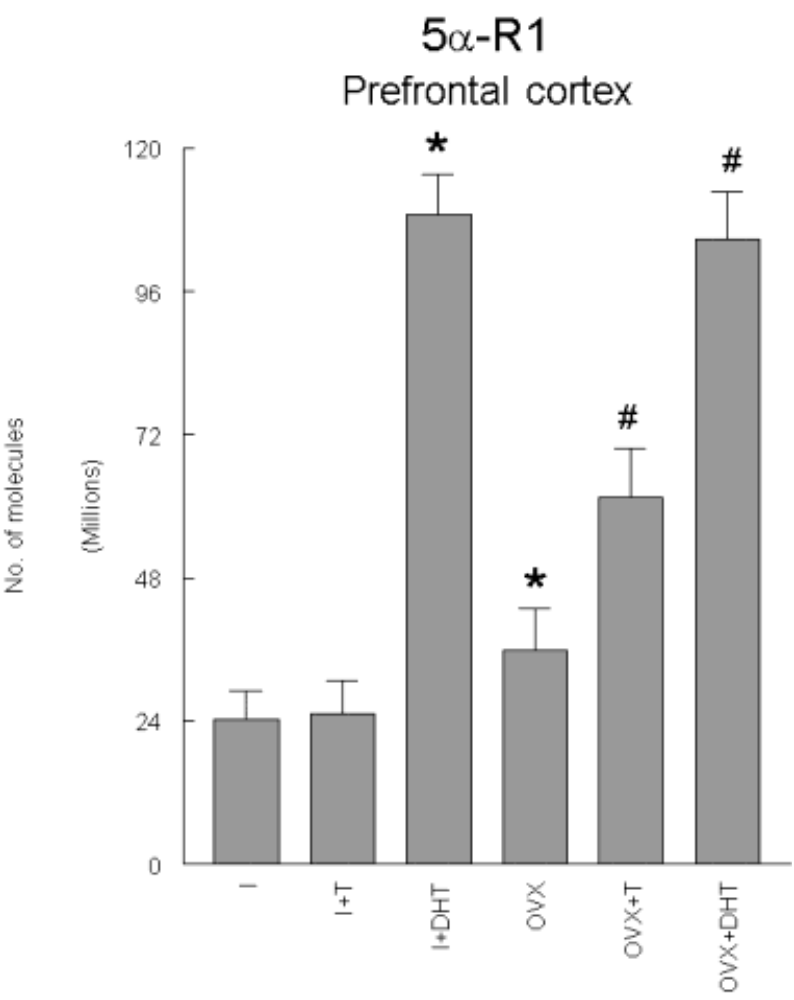

Figure 1 Effects of testosterone $(\mathrm{T})$ and dihydrotestosterone (DHT) on steroid $5 \alpha$-reductase type $1(5 \alpha-R 1)$ mRNA levels of intact (I) and ovariectomized (OVX) animals in prefrontal cortex of adult female rat. ${ }^{*} P<0.01$ or less versus I animals. $\# P<0.01$ or less versus OVX animals.

Fig. 2. The $5 \alpha-R 2$ mRNA levels in I animals were 1.5-fold than in OVX animals. After T treatment, there was a significant increase in $5 \alpha-\mathrm{R} 2 \mathrm{mRNA}$ levels in both I and OVX animals, in comparison with their pre-treatment levels $(3 \cdot 5$-fold for I and $4 \cdot 6$-fold for OVX animals, respectively). After DHT treatment, there was an increase in $5 \alpha-\mathrm{R} 2 \mathrm{mRNA}$ levels in both I and OVX animals in comparison with their respective pretreatment levels. This increase was only significant in I animals $(2 \cdot 0$-fold for I and $1 \cdot 2$-fold for OVX animals, respectively).

\section{Discussion}

Determination of the mRNA levels of specific genes may allow an estimation of gene expression. The present paper aimed to study the mRNA levels of both $5 \alpha-\mathrm{R}$ isozymes and their regulation by $\mathrm{T}$ and DHT in the prefrontal cortex of adult female rats. The results of our experiments demonstrated that both $5 \alpha-\mathrm{R}$ mRNAs are expressed in prefrontal cortex of the adult female rat and that $5 \alpha-\mathrm{R} 1$ is much more abundant than $5 \alpha-\mathrm{R} 2$ (Lephart 1993). This wide disparity (abundance of

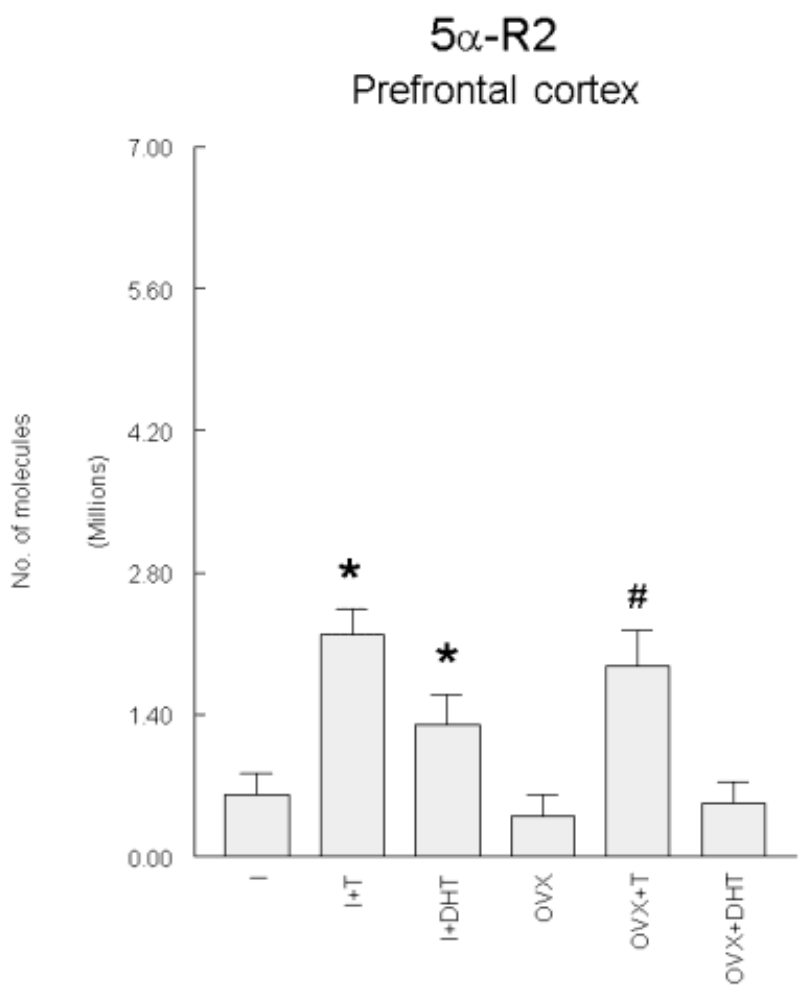

Figure 2 Effects of testosterone $(T)$ and dihydrotestosterone (DHT) on steroid $5 \alpha$-reductase type 2 ( $5 \alpha$-R2) mRNA levels of intact (I) and OVX animals in prefrontal cortex of adult female rat. ${ }^{*} P<0.01$ or less versus I animals. $\# P<0.01$ or less versus OVX animals.

$5 \alpha-\mathrm{R} 1 \mathrm{mRNA}$ was 40 -fold that of $5 \alpha-\mathrm{R} 2)$ may have physiological relevance. Although both isozymes have affinity for the same substrates (progesterone>testosterone> androstenedione $>$ corticosterone), the affinity of $5 \alpha-\mathrm{R} 1$ is much lower than that of 5a-R2 (Negri-Cesi et al. 1996). According to their respective $V_{\max }$ values, $5 \alpha-\mathrm{R} 1$ has a much greater capacity to reduce these substrates compared with 5 $\alpha-\mathrm{R} 2$ (Negri-Cesi et al. 1996). The values of these kinetic parameters indicated that $5 \alpha-\mathrm{R} 1$ could only act when steroid levels were high. The high $\mathrm{V}_{\max }$ of $5 \alpha-\mathrm{R} 1$ endows it with a great capacity to reduce steroids at $5 \alpha$, and for this reason $5 \alpha-\mathrm{R} 1$ has been associated with purely catabolic actions, protecting neurons from excess of glucocorticoids that may induce apoptotic processes (Mahendroo et al. 1997, Poletti et al. $1998 a$ ). In contrast, a substantially high $5 \alpha-\mathrm{R} 2 \mathrm{mRNA}$ levels was found in spinal cord (SC) (Pozzi et al. 2003), an observation perfectly in agreement with recent findings that indicate $5 \alpha-\mathrm{R} 2$ immunoreactive material in adult rat $\mathrm{SG}$ is much higher than those of $5 \alpha-\mathrm{R} 1$ (Patte-Mensah et al. 2004).

Despite the reported association of $5 \alpha-\mathrm{R} 2$ with brain masculinization processes (Poletti et al. 1998b), our results demonstrate that both $5 \alpha-\mathrm{R}$ mRNAs are present in the 
prefrontal cortex of adult female rats with a higher abundance $(3 \cdot 6$-fold for $5 \alpha-\mathrm{R} 1$ and $2 \cdot 2$-fold for $5 \alpha$-R2) than those previously observed by our group in adult males (Torres \& Ortega 2003a). However, no sex difference was observed in the distribution of $5 \alpha-\mathrm{R} 1$ and $5 \alpha-\mathrm{R} 2$ immunoreactive elements in the SC of adult female and male rats (Patte-Mensah et al. 2004).

According to the previous findings observed in the $\mathrm{SC}$ (Patte-Mensah et al. 2004) the 5 $\alpha$-R2 mRNA levels were not significantly modified two weeks after castration in the prefrontal cortex of female rats. $5 \alpha-\mathrm{R} 2 \mathrm{mRNA}$ is much less regulated by $\mathrm{T}$ (5-fold and 26-fold in I and castrated animals, respectively) and DHT (3-fold and 13-fold in I and castrated animals, respectively) in females than in males (Torres \& Ortega 2003a). A possible explanation may be that the steroid milieu during the neonatal period irreversibly imprints or programs $5 \alpha-\mathrm{R} 2$ expression, as this occurs with other hepatic enzymes (Gustafsson \& Stenberg 1974a,b). Another possible explanation may be genetic differences in $5 \alpha-\mathrm{R} 2$ between males and females. Our findings are in accordance with previous reports that treatment with an androgen receptor (AR) blocker, flutamide, produces a significant decrease in the $5 \alpha-\mathrm{R} 2 \mathrm{mRNA}$ levels in the brain of male animals, whereas it is less effective in modulating the expression of this isoform in female brain (Poletti et al. 1998b). In our opinion, the slight regulation of $5 \alpha-\mathrm{R} 2$ by androgen suggests that the production of a large amount of DHT may not be the main function of this isozyme in the female, unlike in the male.

We consider our $5 \alpha-\mathrm{R} 1$ results to be of major interest. The mRNA levels of this isozyme are highly regulated by DHT in both I and OVX animals, and are not regulated by $\mathrm{T}$ in $\mathrm{I}$ females. These results are surprising, because it is known that both T and DHT bind to AR, although the affinity of DHT is four-fold that of T.

There are various possible explanations of our findings, including: a) The long-established aromatization of $\mathrm{T}$ to estradiol in the brain (MacLusky \& Naftolin 1981). Thus, T and DHT may exert different physiological effects, given that DHT would act via AR and $\mathrm{T}$ would act via estrogen receptors. Unfortunately, the hormonal levels in the cerebral cortex have not been measured in this work. It is generally accepted that the aromatase enzyme depends on the androgenic status of animals. Thus, castration decreases aromatase activity and mRNA levels, whereas $\mathrm{T}$ treatment restores them (Harada et al. 1992, Abdelgadir et al. 1994). Cytochrome P450 aromatase has been found in neurons from the cerebral cortex of neonatal rats (Zwain \& Yen 1999). However, other authors have been found that aromatase is mainly localized in specific brain areas such as the hypothalamus-preoptic area but not in the cerebral cortex (Lephart 1996, Kato et al. 1997). In vitro studies have also demonstrated that $\mathrm{T}$ increases hypothalamic but not cortical aromatase (Beyer et al. 1994). Given that we administered $\mathrm{T}$ and DHT systemically, the peripheral aromatization of $\mathrm{T}$ should be borne in mind. Nevertheless, the females show higher hepatic $5 \alpha-\mathrm{R}$ activity and mRNA levels compared with males (Gustafsson \& Stenberg 1974a,b, Torres \& Ortega 2003c, $2004 b$ ); thus, the aromatization of $\mathrm{T}$ would be greater in males than in females. Hence, the differential effects of $\mathrm{T}$ and DHT on $5 \alpha-\mathrm{R} 1$ found in the present study cannot be attributed solely to the conversion of $\mathrm{T}$ to estradiol but rather indicate a sexually dimorphic regulation of the enzyme. b) The possible metabolism of DHT into

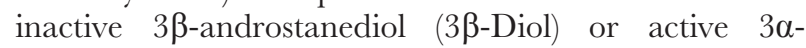
androstanediol ( $3 \alpha-\mathrm{Diol})$, as occurs in the pituitary (Denef et al. 1974). In general, reduction at the C3 position decreases the binding affinity to intracellular receptors (Negri-Cesi et al. 1996) such as AR. The enzyme $3 \alpha$-hydroxyesteroid oxidoreductase ( $3 \alpha-\mathrm{HSOR})$ is present in the cerebral cortex, although the formation of $3 \alpha$-Diol is generally lower in the cerebral cortex than in white matter (Negri-Cesi et al. 1996). c) Finally, the differential effect of T and DHT on $5 \alpha-\mathrm{R} 1$ may be due to the existence of different classes of androgenresponsive elements (Russell \& Wilson 1994) and different signaling pathways. The differences observed in the response to androgens between I and OVX rats could be attributed to the influence of some ovarian factors. Perhaps, the lack of ovaries may compensate for a different hormonal background, allowing for direct downregulation of T- or DHT-modulated transcription factors such as AR.

$5 \alpha-\mathrm{R} 1 \mathrm{mRNA}$ in the female is drastically increased by DHT in an opposing way to that observed previously by our group in the male (Torres \& Ortega 2003a). These data demonstrate that $5 \alpha-\mathrm{R} 1$ presents a major sexual dimorphism in the brain, at least in the prefrontal cortex, and may therefore be involved in sexual dimorphism throughout the female's life. $5 \alpha-\mathrm{R} 1$ has to date been considered a constitutive enzyme associated with purely catabolic actions. However, the present results broaden this concept, because $5 \alpha-\mathrm{R} 1 \mathrm{mRNA}$ was shown to be highly and positively regulated by DHT, an steroid lacking $\Delta^{4,5}$ double bond. Furthermore, the mRNA profile of $5 \alpha-\mathrm{R} 1$ in the cerebral cortex of the adult female rat is different from its profile in the liver (Torres \& Ortega 2004b), which is the catabolic organ par excellence.

If the function of $5 \alpha-\mathrm{R} 1$ in the female is not solely catabolic and the function of $5 \alpha-\mathrm{R} 2$ in the female is not the production of the potent androgenic hormone DHT, the question arises as to the function of these isozymes in the female brain. One possibility is that, in addition to the catabolic effects of $5 \alpha-\mathrm{R} 1$, both $5 \alpha-\mathrm{R}$ isozymes intervene in the production of a $5 \alpha$-reduced progesterone derivative, this hypothesis is supported by several findings. $5 \alpha-\mathrm{R} 2 \mathrm{mRNA}$ is slightly regulated by 
androgens, as we report in this paper. $5 \alpha-\mathrm{R} 2 \mathrm{mRNA}$ has been induced in the hippocampus of female mice by progesterone, producing $5 \alpha$-reduced metabolites (Matsui et al. 2002). Both $5 \alpha-\mathrm{R}$ isozymes have a higher affinity for progesterone than for other steroid substrates. Circulating progesterone levels are higher in the female than in the male.

The $5 \alpha$-reduced steroid may be transformed by action of the enzyme $3 \alpha-\mathrm{HSOR}$, also present in the CNS, into the $3 \alpha 5 \alpha$-reduced progesterone derivative allopregnanolone. This compound is a potent neurosteroid whose action is mediated by allosteric modulation of the $\mathrm{GABA}_{\mathrm{A}}-\mathrm{R}$ complex (Mellon \& Griffin 2002). Neurosteroids are steroids produced within the nervous system of vertebrates (Baulieu 1998, Mensah-Nyagan et al. 1999, Patte-Mensah et al. 2003) which are involved in the regulation of stress responses, anxiety, sleep, aggressive behavior and other important neurobiological processes in the CNS and peripheral nervous system (Purdy et al. 1991, Majewska 1992, Melcangi et al. 2005, Patte-Mensah et al. 2005).

We previously reported that the neonatal administration of the GABA agonist diazepam to male rats feminizes behavior and CNS structures (Segovia et al. 1996,1999). 3a5a-reduced neurosteroids regulate $\mathrm{GABA}_{\mathrm{A}}$ receptors in a similar way to barbiturates (Majewska 1992, Paul \& Purdy 1992) and may therefore exert similar effects in the CNS, favoring the formation and maintenance of female brain structures. This would offer a biological explanation for the greater levels of $3 \alpha 5 \alpha$-reduced neurosteroids (Torres \& Ortega 2003b) and of both $5 \alpha-\mathrm{R}$ isozymes in the female versus male brain.

Our group previously demonstrated that DHT regulates $5 \alpha-\mathrm{R} 2$ in the prostate and brain of male rats by a feed-forward mechanism (Torres \& Ortega 2003a, Torres et al. 2003). We argued that $5 \alpha-\mathrm{R} 2$ may act in the male as morphogen (George et al. 1991, Russell \& Wilson 1994) throughout the life of the individual, favoring the maintenance of essentially masculine structures, this is consistent with the idea of DHT as androgenic. Now, we demonstrated for the first time that DHT positively regulates the mRNA levels of both $5 \alpha-R$ isozymes in the I female. Therefore, DHT could feminize brain structures (Valencia et al. 1992) by an increase in $3 \alpha 5 \alpha$-reduced neurosteroids through the induction of $5 \alpha-\mathrm{R}$ isozymes.

To our best knowledge, our data provide the first evidence that both $5 \alpha-\mathrm{R}$ isozymes are present in the brain of adult female rats, at least in the prefrontal cortex, and that their mRNA levels are regulated by androgens in a different way than in the male. Whereas $5 \alpha-\mathrm{R} 2 \mathrm{mRNA}$ is slightly regulated by $\mathrm{T}$ and DHT, $5 \alpha-\mathrm{R} 1 \mathrm{mRNA}$ is very positively regulated by DHT. In our opinion, both $5 \alpha-\mathrm{R}$ isozymes may participate in the production of $3 \alpha 5 \alpha$-reduced neurosteroids, although
$5 \alpha-\mathrm{R} 1$ may act when the steroid levels are higher. The data showed in this work indicate the great sexual dimorphism in the CNS with respect to the two $5 \alpha-\mathrm{R}$ isozymes and could point to their possible participation in the development and maintenance of sexually dimorphic structures throughout the life of the female. Interestingly, DHT, an essentially androgenic hormone, may feminize the CNS through $5 \alpha-\mathrm{R}$ isozymes.

\section{Acknowledgements}

We thank R Davies for revising the English text. This work was founded in part by FIS PI-021625, Red Endoc. y Nutr. Instituto de Salud Carlos III, and the Andalusian Regional Government (Endocrinology \& Metabolism Group). The authors declare that there is no conflict of interest that would prejudice the impartiality of this scientific work.

\section{References}

Abdelgadir SE, Resko JA, Ojeda SR, Lephart ED, McPhaul MJ \& Roselli CE 1994 Androgens regulate aromatase cytochrome P450 messenger ribonucleic acid in rat brain. Endocrinology 135 395- 401.

Baulieu EE 1998 Neuroteroids: a novel function of the brain. Psychoneuroendocrinology 23 963-987.

Beyer C, Green SJ \& Hutchison JB 1994 Androgens influence sexual differentiation of embryonic mouse hypothalamic aromatase neurons in vitro. Endocrinology 135 1220-1226.

Chomczynski P \& Sacchi N 1987 Single-step method of RNA isolation by acid guanidinium thiocyanate-phenol-chloroform extraction. Analytical Biochemistry 162 156-159.

Denef C, Magnus C \& McEwen BS 1974 Sex-dependent changes in pituitary 5 alpha-dihydrotestosterone and 3 alpha-androstanediol formation during postnatal development and puberty in the rat. Endocrinology 94 1265-1274.

George FW, Russell DW \& Wilson JD 1991 Feed-forward control of prostate growth: dihydrotestosterone induces expression of its own biosynthetic enzyme, steroid 5 alpha-reductase. PNAS $888044-8047$.

Gustafsson JA \& Stenberg A $1974 a$ Irreversible androgenic programming at birth of microsomal and soluble rat liver enzymes active on androstene-3,17-dione and 5-alpha-androstane-3 alpha, 17 beta-diol. Foumal of Biological Chemistry 249 711-718.

Gustafsson JA \& Stenberg A $1974 b$ Neonatal programming of androgen responsiveness of liver of adult rats. Fournal of Biological Chemistry 249 719-723.

Harada N, Yamada K, Foidart A \& Balthazart J 1992 Regulation of aromatase cytochrome P-450 (estrogen synthetase) transcripts in the quail brain by testosterone. Brain Research and Molecular Brain Research 15 19-26.

Kato J, Yamada-Mouri N \& Hirata S 1997 Structure of aromatase mRNA in the rat brain. Fournal of Steroid Biochemistry and Molecular Biology $61381-385$.

Lauber ME \& Lichtensteiger W 1996 Ontogeny of $5 \alpha$-reductase (Type 1) messenger ribonucleic acid expression in rat brain early presence in germinal zones. Endocrinology 137 2718-2730.

Lephart ED 1993 Brain 5 $\alpha$-reductase: cellular, enzymatic, and molecular perspectives and implications for biological function. Molecular and Cellular Neuroscience 4 473-484. 
Lephart ED 1996 A review of brain aromatase cytochrome P450. Brain Research and Brain Research Reviewes 22 1-26.

MacLusky NJ \& Naftolin F 1981 Sexual differentiation of the central nervous system. Science 211 1294-1302.

Mahendroo MS, Cala KM, Landrum DP \& Russell DW 1997 Fetal death in mice lacking 5 alpha-reductase type 1 caused by estrogen excess. Molecular Endocrinology 11 917-927.

Majewska MD 1992 Neurosteroids: endogenous bimodal modulators of the GABAA receptor. Mechanism of action and physiological significance. Progress in Neurobiology 38 379-395.

Matsui D, Sakari M, Sato T, Murayama A, Takada I, Kim M, Takeyama K \& Kato S 2002 Transcriptional regulation of the mouse steroid 5-alpha-reductase type II gene by progesterone in brain. Nucleic Acids Research 30 1387-1393.

Melcangi RC, Celotti F, Castana P \& Martini L 1993 Differential localization of the 5 alpha-reductase and the 3 alphahydroxysteroid dehydrogenase in neuronal and glial cultures. Endocrinology 132 1252-1259.

Melcangi RC, Poletti A, Cavarretta I, Celotti F, Colciago A, Magnaghi V, Motta M, Negri-Cesi P \& Martini L 1998 The $5 \alpha$-reductase in the central nervous system: Expression and modes of control. Fournal of Steroid Biochemistry and Molecular Biology 65 295-299.

Melcangi RG, Cavarretta I, Ballabio M, Leonelli E, Schenone A, Azcoitia I, Garcia-Segura LM \& Magnaghi V 2005 Peripheral nerves: a target for the action of neuroactive steroids. Brain Research Reviewes 48 328-338.

Mellon SH \& Griffin LD 2002 Neurosteroids: biochemistry and clinical significance. Trends in Endocrinology and Metabolism 13 35-43.

Mensah-Nyagan AG, Do-Rego JL, Beaujean D, Luu-The V, Pelletier G, Vaudry H 1999 Neurosteroids: expression of steroidogenic enzymes and regulation of steroid biosynthesis in the central nervous system. Pharmacological Reviewes 51 63-81.

Negri-Cesi P, Poletti A \& Celotti F 1996 Metabolism of steroids in the brain: a new insight into the role of 5 alpha-reductase and aromatase in brain differentiation and functions. Fournal of Steroid Biochemistry and Molecular Biology 58 455-466.

Patte-Mensah C, Kappes V, Freund-Mercier MJ, Tsutsui K \& Mensah-Nyagan AG 2003 Cellular distribution and bioactivity of the key steroidogenic enzyme, cytochrome P450 side chain cleavage, in sensory neural pathways. Fournal of Neurochemistry 86 1233-1246

Patte-Mensah C, Penning TM \& Mensah-Nyagan AG 2004 Anatomical and cellular localization of neuroactive 5 alpha/ 3 alpha-reduced steroid-synthesizing enzymes in the spinal cord. Journal of Comparative Neurology 477 286-299.

Patte-Mensah C, Kibaly C \& Mensah-Nyagan AG 2005 Substance P inhibits progesterone conversion to neuroactive metabolites in spinal sensory circuit: a potential component of nociception. PNAS $1029044-9049$

Paul SM \& Purdy RH 1992 Neuroactive steroids. FASEB fournal 6 2311-2322.

Pelletier G, Luu-The V \& Labrie F 1994 Immunocytochemical localization of 5 alpha-reductase in rat brain. Molecular and Cellular Neurosciences 5 394-399.

Poletti A, Celotti F, Rumio C, Rabuffetti M \& Martini L 1997 Identification of type 15 alpha-reductase in myelin membranes of male and female rat brain. Molecular and Cellular Endocrinology 129 181-190.
Poletti A, Coscarella A, Negri-Cesi P, Colciago A, Celotti F \& Martini L 1998a 5-alpha-reductase isozymes in the central nervous system. Steroids 63 246-251.

Poletti A, Negri-Cesi P, Rabuffetti M, Colciago A, Celotti F \& Martini L $1998 b$ Transient expression of the 5 alpha-reductase type 2 isozyme in the rat brain in late fetal and early postnatal life. Endocrinology 139 2171-2178.

Pozzi P, Bendotti G, Simeoni S, Piccioni F, Guerini V, Marron TU, Martini L \& Poletti A 2003 Androgen 5-alpha-reductase type 2 is highly expressed and active in rat spinal cord motor neurones. Fournal of Neuroendocrinology 15 882-887.

Purdy RH, Morrow AL, Moore PH Jr \& Paul SM 1991 Stress-induced elevations of gamma-aminobutyric acid type A receptor-active steroids in the rat brain. PNAS 88 4553-4557.

Russell DW \& Wilson JD 1994 Steroid 5a-Reductase: Two genes/two enzymes. Annual Review of Biochemistry 63 25-61.

Segovia S, del Cerro MCR, Ortega E, Perez-Laso C, Rodriguez M, Izquierdo MAP \& Gillamon A 1996 Role of GABA A receptors in the organization of brain and behavioural sex differences. Neuroreport 7 2553-2557.

Segovia S, Guillamon A, del Cerro MCR, Ortega E, Perez-Laso C, Rodriguez M \& Beyer C 1999 The development of brain sex differences: a multisignaling process. Behavioural Brain Research $10569-80$.

Torres JM \& Ortega E $2003 a$ Differential regulation of Steroid $5 \alpha$-Reductase isozymes expression by androgens in the adult rat brain. FASEB Fournal 17 1428-1433.

Torres JM \& Ortega E $2003 b$ Alcohol intoxication increases allopregnanolone levels in female adolescents human. Neuropsychopharmacology 28 1207-1209.

Torres JM \& Ortega E 2003c Precise quantitation of 5 alphareductase type $1 \mathrm{mRNA}$ by RT-PCR in rat liver and its positive regulation by testosterone and dihydrotestosterone. Biochemical and Biophysical Research Communications 308 469-473.

Torres JM \& Ortega E 2004a Quantitation of mRNA levels of steroid $5 \alpha$-reductase isozymes. A novel method that combines RT-PCR and capillary electrophoresis. International Fournal of Biochemistry \& Cell Biology 36 78-88.

Torres JM \& Ortega E $2004 b$ Precise quantitation of steroid $5 \alpha$-reductase type 1 mRNA levels by RT-PCR in female rat liver. Endocrine Research 30 149-157.

Torres JM, Ruiz E \& Ortega E 2003 Development of a quantitative RT-PCR method to study $5 \alpha$-reductase mRNA isozymes in rat prostate in different androgen status. Prostate 56 74-79.

Torres JM, Sánchez P \& Ortega E 2004 Quantitation of mRNA levels of steroid 5 alpha-reductase isozymes in the rat brain by 'one-step' RT-PCR and capillary electrophoresis. Foumal of Neuroscience Methods 136 105-110.

Valencia A, Collado P, Cales JM, Segovia S, Perez-Laso C, Rodríguez-Zafra M \& Guillamon A 1992 Postnatal administration of dihydrotestosterone to the male rat abolishes sexual dimorphism in the accessory olfactory bulb: a volumetric study. Developmental Brain Research 8 132-135.

Zwain IH \& Yen SS 1999 Neurosteroidogenesis in astrocytes, oligodendrocytes, and neurons of cerebral cortex of rat brain. Endocrinology 140 3843-3852.

Received 12 November 2005 Accepted 12 December 2005 Made available online as an Accepted Preprint 13 December 2005 